\title{
Rhyming in the Context of the Phonological Awareness of Pre-School Children
}

SoŇA GROFČíKOVÁ ${ }^{* 1}$ AND MoniKa MáČAJOVÁ ${ }^{2}$

$\approx$ Rhyming is one of the basic skills associated with phonological awareness. This paper aims to introduce theoretical starting points and the results of research into children's rhyming in the context of phonological awareness. The text explains theoretical circumstances pertaining to the theme and defines key concepts. The main part of the paper includes the results of the research of pre-school children in Slovakia. There were 866 respondents (children) of 4 to 7 years of age. The subject of the research was the rhyming skills of children, which was tested in three independent areas: completing the rhyme in a nursery-rhyme, awareness of rhymes, and the production of rhymes.

Keywords: rhyming, rhyme, phonological awareness, nursery-rhyme, rhyme awareness, rhyme production

$1{ }^{*}$ Corresponding Author. Faculty of Education, Constantine the Philosopher University Nitra, Slovakia; sgrofcikova@ukf.sk.

2 Faculty of Education, Constantine the Philosopher University Nitra, Slovakia. 


\section{Rima v kontekstu fonološke ozaveščenosti predšolskih otrok}

SoŇA GrofČíkOvá In Monika MáčAJOvá

$\approx$ Rimanje je ena izmed osnovnih veščin fonološkega zavedanja. V prispevku so predstavljena teoretična izhodišča in izsledki raziskav o rimanju otrok v kontekstu fonološkega zavedanja. V nadaljevanju so podana teoretična dejstva $\mathrm{v}$ povezavi $\mathrm{z}$ navedeno temo in opredeljeni njeni ključni termini. Osrednji del prispevka je namenjen izsledkom raziskave predšolskih otrok na Slovaškem, v kateri je sodelovalo 866 otrok v starosti od 4 do 7 let. Predmet raziskave so bile veščine rimanja pri otrocih, preverjene na treh neodvisnih področjih: dokončanje rime v otroški pesmi, zavedanje rime in rimanje.

Ključne besede: rimanje, rima, fonološko zavedanje, otroška pesem, zavedanje rime, rimanje 


\section{Introduction}

The initial teaching of reading as well as the preceding preparation of children for reading have long been primarily associated with the development of sight perception and focused on the mutual harmonising of eye movements with the movement of the hand. When a child was failing in the acquisition of reading and writing, the reason was sought specifically in the area of the processing of visual information; this was supported by many research studies in reading, which were connected with a relatively intensive interest in sight-perception or sight-spatial processes in reading. However, research into language teaching began to indicate that problems with reading and writing largely result from the shortcomings in processing not visual but acoustic information. Recently, theoretical and empirical findings have shown that phonological factors are involved in the process of mentally representing written words (Ehri, 1992 in Wimmer et al., 1994). There have been growing doubts that we read primarily with sight, especially in connection with the growing knowledge regarding the importance of phonological skills in reading. Many studies have shown that the awareness of the phonological structure of spoken speech, distinguishing phonological units (words, syllables, morphemes and, especially, phonemes), including the ability to work effectively with them at the level of operational memory, is, from the aspect of learning to read, much more important, if not even decisive (Adams, 1990; McBride-Chang, 1995; Mann \& Foy, 2007; Torgesen, 2002).

\section{Theoretical background}

Each of the elements of literacy is unique; talking, listening, and paying attention are expected to occur without any specific interventions. However, reading and writing are activities based on experience, relying on the child's capabilities (hear, see, say, and store words) and on specific activities encouraging the skills of visual and auditory discrimination, physical maturity, particularly of fine motor control, underpinned by a desire to communicate (Featherstone, 2017). Therefore, language literacy is one of the most important competences in life, which predicts later development of critical and creative thinking. Rhyme awareness, the ability of children to become aware of and produce rhymes are the essential abilities developed at the level of pre-primary and the beginning of primary education of children. One of the starting points and arguments for their development is the fact that rhyme awareness may be a significant help in the development of phonological awareness in case of some beginning readers. Performance in the rhyming tasks is a predictor of the later success in reading 
(Catts et al., 2001; Culatta et al., 2007). The essence lies in the fact that the identification of rhyme requires the child to hear sounds within words, which gives the child a basic idea that the word is divided into sound parts. The awareness of syllables and rhymes is developed prior to literacy, but the awareness of the smallest elements of sound symbolised by letters (phonemes) is changed with the orthographical transparency of language. It is necessary to work on skills such as letter recognition, as well as sound and phonological awareness. Research results demonstrate the importance of phonological awareness for ongoing literacy development.

Furthermore, the importance of working in a structured way to develop phonological awareness in children at risk of having future reading and writing difficulties is underscored (Andersson et al., 2019). A strong causal link exists between rhyming skills and reading. Children with weak phonological skills and decreased sensitivity to rhythm are at risk of dyslexia; therefore, the exercises improving rhyme awareness in language (based on music, poetry) may make reading development easier (Goswami, 2015). Also, research findings (Ozernov-Palchik et al., 2018) suggest a connection among rhythm perception, phonological awareness, and letter-sound knowledge (a significant precursor of reading); the authors determined that 'the association between rhythm perception and letter-sound knowledge is mediated through phonological awareness' (p. 354).

Phonological awareness is a term that is frequently substituted by phonemic awareness. Phonological awareness denotes the conscious ability to differentiate and manipulate phonological units bigger than individual phonemes (syllables and rhymes), while phonemic awareness is associated only with the smallest units: the phonemes (Ehri et al., 2001; Hogan et al., 2005; Moats, 2000; Reading \& Deuren, 2007). Phonological awareness is understood as a general concept of the awareness of sound units, either words, syllables, onsets, and rimes or phonemes, which play a crucial role in this process (Anthony \& Francis, 2005; Grofč́́ková \& Máčajová, 2017). Phonological awareness is the ability to pay attention to the sound structure of words, to divide and manipulate sounds. Children learn the sounds and their combinations that are present in their languages and thus form phonological representations for real words. Reading acquisition is predicted by the quality of these representations (Goswami, 2015; McBride-Chang, 1995). Nagy and Anderson (1995) ask whether in the case of the youngest children's representations of words involve phonemic units at all. In the beginning, words may be represented from the point of view of bigger units, analysed into phonemes only when the discrimination of phonemes is necessary, that is, in the case of the child's growing vocabulary. Adams (1990) distinguished 
four skills that form the basis of phonological awareness. They include rhyming, division of words into syllables, isolating individual sounds (acoustic analysis), joining syllables and sounds (acoustic synthesis), and manipulating sounds (phoneme awareness). As a skill related to phonological awareness, rhyming requires considering that similar sounding words differ in their onset and are the same in their final part. Phoneme awareness is thus acquired by the child in the following order (Cséfalvay \& Lechta, 2013):

1. the rhyming of words begins with rhyme perception, then gradually becoming aware of the fact that, for example, the word 'cat' rhymes with the word 'hat';

2. division of words into syllables;

3. identification of the first syllable in the word (the word 'water' begins with the syllable /wa/);

4. identification of the last syllable in the word (the word 'computer' ends with the syllable /ter/);

5. identification of the first sound in the word (the word 'cat' begins with $/ \mathrm{k} /)$;

6. identification of the last sound in the word (the word 'hat' ends with $/ t /$ );

7. identification of the sounds in a word with CVC form (e.g., 'cat'), CCVC (e.g., 'skin') and other longer words, to compose words of sounds (trousers, rhinoceros, and so on), segmenting the words into individual phonemes;

8. manipulation and play with sounds in words and exchanges of sounds, deletion of concrete phonemes in the word.

Four operations are required from the child in the process of phonological awareness. The first is the acoustic perception of certain speech segments. Subsequent to this is its retention in memory sufficiently long for the required operation to be carried out. Then the performance of the given operation (manipulation, leaving out, identification, etc. of speech segment) and the result of the operation must be communicated, most often orally (McBride-Chang, 1995). The development of the concept of phonemes and joining the letters with sounds depends on the ability to listen to the sounds of words and analyse the sounds of individual components. It is thus not surprising that training the awareness of sound units bigger than phonemes accelerates the process of reading. The development of phonological awareness in the pre-school age occurs when it is specifically trained. A striking development of phonological awareness then takes place when the beginning reader begins to be formally educated and trained in the manipulation with sounds and letters, as well as in their 
correspondence. The skill to search for words that rhyme is an indicator of the feeling for language, of the ability to perceive the sound structure of words and to become aware of the identity, and, at the same time, the onomatopoeic nature of the last syllable (Máčajová et al., 2017).

Both speech and nonlinguistic rhythm processing require accurate processing of the temporal structure in acoustic stimuli. Temporal patterns in speech contain important cues to phonological units such as phonemes, syllables, and stresses. These collective cues help language learners to segment syllables and words from the acoustic stream and develop a phonological template (Ozernov-Palchik et al., 2018, p. 364).

Phonological awareness is a crucial skill for reading acquisition. Therefore, performing on PA tasks is considered to be a strong predictor of later reading success or impairment.

Rhyme is characterised by the acoustic agreement of sounds (vowels and consonants), words or a group of words at the end of lines, or half-lines. To be able to rhyme requires understanding the concept of rhyming and having the abilities that are key components of the phonological awareness (as discussed above) specifically how to segment words, delete sounds, substitute sounds, and join sounds into words. The child must know which part of the word is important in the rhyme. A child who does not have a sufficient feeling for rhyme often concentrates on the first or last sound of the word, or rather on the meaning of the word, than on the entire rime. Such children, for example, say that 'hat' and 'coat' rhyme (rime is the second half of the word h-at, c-oat). They can also have difficulty with multi-syllable words. Nonsense words are acceptable for the creation of rhymes, because they point to the ability to create a rhyme, not to knowing vocabulary (Adams et al., 1998), which was also confirmed in the results of our testing via our Test of Phonological and Phonematic Awareness (Máčajová, 2013). Such neologisms were not considered to be wrong. The basic instrument for the development of the ability of children to work with rhymes is nursery-rhymes, which are a frequently used genre aimed at children, with appealing aesthetics in rhythm, rhyme, intonation, instruction, entertainment, and fantasy. As for their extent, they are short verse formations, rhythmical texts in which sound instrumentation prevails. It is the connection of the text with a concrete situation or characterising a situation by its naming. The theory understands nursery-rhymes as the characteristic talking of children or adults to animals, plants, or various effects and phenomena in nature. In the nursery rhyme, the rhythmic qualities of an utterance are actualised with a certain aim, 
which is associated with the content of the text and has a form of play; This is one of the reasons that nursery-rhymes gradually became part of children's play. In verbal play, children learn how to distinguish verbal models, and then use this knowledge in reading and building their vocabulary (Žilka, 2011).

Rhythm is a regular repeating of the same or similar phenomena in their temporal or spatial succession. It is the regular repeating of an acoustic element, which is associated with the phonetic and phonological system of the language. The repeating can be carried out through the alternation of long and short syllables, through the same number of syllables or accents in the verse, which is the basic unit of poetic rhythm, usually one line of a poetic text. It is characterised by its sound structure which is based either on the regular distribution of stressed and unstressed syllables or on the regular alternation of long and short syllables. This sound organisation is repeated in several verses (Žilka, 2011). The subject of many scholarly discussions is the question of whether rhyme awareness in the early age of the child is significant for the subsequent reading acquisition. Various research studies have proposed several hypotheses:

1. rhyme awareness relates to the ability to read,

2. rhyme awareness influences the acquired level of reading (performance),

3. rhyme awareness leads to the development of phonemic awareness.

This paper presents just one part of a larger study whose aim was to create, for the purposes of pedagogical diagnostics, the Test for the Evaluation of Phonological and Phonemic Awareness (Máčajová, 2013) for pre-school age children, which consists of five main areas, each of which is focused on testing various skills within sub-areas:

- $\quad$ rhyme (described below; there are 15 tested items);

- analysis and synthesis (word-to-syllable analysis, word-to-sound analysis, synthesis of syllables into words, synthesis of sounds into words; there are 40 tested items);

- $\quad$ omission (sound omitting, syllable omitting: there are 10 tested items);

- auditory isolation (isolation of the initial sound, isolation of the initial syllable, creation of the word with particular sound; there are 15 tested items);

- $\quad$ auditory differentiation and localisation (differentiation of words with visual support (pictures), differentiation of words without visual support, localisation of changes within the sentence, localisation of changes within the word, differentiation of nonsense words; there are 25 tested items).

In this paper, we have focused on the detection of the following abilities 
in the work with rhymes:

1. ability of children to complete rhyme in a known child's nursery-rhyme;

2. ability to become aware of rhyme, i.e., to determine whether two words rhyme;

3. ability to produce (create) rhymes.

Drawing on the above, we were interested in obtaining answers for the following research questions: What is the level of children, in all age categories, in the fields completing the rhyme in nursery-rhymes, rhyme awareness, production of rhymes?

\section{Method}

The research included 28 kindergartens, which were selected by random choice of a western Slovak region. The children tested were from four to seven years of age. In total, there were 866 respondents. Children with speech disorders and those with delayed schooling start were excluded from the testing. In total, we have evaluated 12,990 children's utterances (15 tested items).

\section{Instruments and procedure}

First, we tested the ability of the child to complete the rhyme in a wellknown child's nursery-rhyme. Five familiar Slovak children's nursery-rhymes were tested: 'Ťap-tap-tapušky, išli mačky na hrušky’; 'Osievame múčku, v slamenom klobúčku'; 'Kujem, kujem podkovičku, koníkovi na nožičku'; 'Adam v škole nesedel, abecedu nevedel'; Cip, cip, cipovička, mak, mak, makovička'.

Second, we tested the ability of the child to become aware of the rhyme. The child's task was to assess whether the two words, provided by the administrator, rhyme or do not rhyme. Five pairs of the following words were tested: 'čaj-daj', 'auto-slnko', 'huby-zuby', 'myška-líška', and 'komín-kominár'.

Third, the ability of the child to produce (create) rhymes was tested. The child's task was to create a word rhyming with the stimulus word. The following five words were tested: 'pes' (dog), 'dom' (house), 'deti' (children), 'opica' (monkey), 'hračka' (toy). These test tasks were ordered as the last ones; in ascending order of difficulty.

The obtained data were processed using the ANOVA (Analysis of Variance)statistical method. The test aimed to detect whether the differences in the means of individual groups, detected in the sample, were statistically significant, or merely accidental. ANOVA represents an enlargement of the 
two-sample t-test. If two groups are compared (the factor has just two levels), ANOVA shows the same result as the t-test (Tomšik, 2017). The LSD analysis (Fisher's Least Significant Difference Analysis) was used in the case of obtaining a significant result via the ANOVA analysis, which means that at least one of the tested groups differs from the remaining ones. The LSD analysis is the test of the smallest difference, used when the zero hypothesis is rejected as a consequence of the results of the hypotheses tests. The LSD calculates the smallest difference between two means, which allows a direct comparison of two means from two independent groups (Tomšik, 2017). To measure the strength of the relationship between two continuous (interval) accidental values, we used the Pearson correlation coefficient. The value $\mathrm{r}$ moves from o to $+/-1$. The values close to o signify no relation and the absolute values close to 1 the strong relation. There is a relation between the variables if all points [xi, yi] are on the straight line. It equals zero when the values are independent. Positive values signify that variables tend to change in the same direction, and the negative values in different directions (Tomšik, 2017).

\section{Results}

\section{Table 1}

Percentage success rate of children in rhyme testing

\begin{tabular}{|c|c|c|c|c|c|c|c|}
\hline \multirow{2}{*}{ Variable } & \multicolumn{6}{|c|}{ Age } & \multirow{2}{*}{ Overall } \\
\hline & $4.0-4.5$ & $4.6-5.0$ & $5.1-5.5$ & $5.6-6.0$ & $6.1-6.5$ & $6.6-7.0$ & \\
\hline $\begin{array}{l}\text { Completing the rhyme } \\
\text { in a nursery-rhyme }\end{array}$ & $74.2 \%$ & $80 \%$ & $81 \%$ & $86.8 \%$ & $89.6 \%$ & $90.8 \%$ & $85 \%$ \\
\hline Rhyme awareness & $44.8 \%$ & $56.4 \%$ & $62.4 \%$ & $67.6 \%$ & $79.2 \%$ & $80.8 \%$ & $67 \%$ \\
\hline Rhyme production & $33.4 \%$ & $38.2 \%$ & $48.6 \%$ & $55.6 \%$ & $68.8 \%$ & $72.8 \%$ & $54 \%$ \\
\hline
\end{tabular}

In the first step of the result assessment, we were interested in determining whether there is a statistically significant difference between age categories in individual tested areas (completing the rhyme in nursery-rhymes, rhyme awareness, rhyme production). The ANOVA (Analysis of Variance) test was used for these purposes. Based on the significant results obtained through the ANOVA analysis, we decided to use the LSD test for a more detailed analysis (Fisher's Least Significant Difference Analysis). 
Table 2

Statistical significance of differences in Completing the rhyme in nursery-rhymes

\begin{tabular}{lcccccccc}
\hline Variable & $\begin{array}{c}\text { Age } \\
\text { category }\end{array}$ & Age & N & M & SD & df & F & p \\
\hline 1 & $4.0-4.5$ & 83 & 3.71 & 1.264 & & & \\
& 2 & $4.6-5.0$ & 160 & 4.01 & 1.200 & & & \\
$\begin{array}{l}\text { Completing } \\
\text { the rhyme in a } \\
\text { nursery-rhyme }\end{array}$ & 3 & $5.1-5.5$ & 130 & 4.05 & 1.203 & & & \\
& 4 & $5.6-6.0$ & 192 & 4.34 & .919 & & & \\
& 5 & $6.1-6.5$ & 204 & 4.49 & .791 & & & \\
& 6 & $6.6-7.0$ & 97 & 4.54 & .817 & & & \\
\hline
\end{tabular}

Note. $\mathrm{p}<.05$

The results in Table 2 show that in the tested area completing the rhyme in a nursery-rhyme, the results in all age categories were statistically significant, on the level of significance of .ooo. It may thus be stated that if differences found in individual age categories are assessed, they are statistically significant across the entire research sample. For the interpretation of the results and making a conclusion about the research, of key importance are the results in Table 1, which present the children's success rate in the testing of rhymes. The results in the area completing the rhyme in nursery-rhymes demonstrate that children were improving by age $(74.2 \%, 80 \%, 81 \%, 86.8 \%, 89.6 \%, 90,8 \%)$, meaning that the older the children were, the more successful they were, being able to better complete the rhyme in the tested nursery-rhymes. The comparison of statistical significance of the difference for the entire research sample showed that if the children at the ages of four to seven years are assessed in a complex way, the increase in their ability is highly evident and may be valid for the whole population. To analyse the differences between the individual age categories in more detail, the LSD test was used; its results are shown in Table 3. 


\section{Table 3}

Statistical significance in individual age categories in Completing the rhyme in nursery-rhymes

\begin{tabular}{|c|c|c|c|c|c|c|c|c|c|c|}
\hline Variable & \multicolumn{2}{|c|}{$\begin{array}{c}\text { Age } \\
\text { Category }\end{array}$} & \multirow{2}{*}{$\begin{array}{c}\begin{array}{c}\text { Mean } \\
\text { Difference } \\
(\mathrm{I}-\mathrm{J})\end{array} \\
-.295^{*}\end{array}$} & \multirow{2}{*}{$\begin{array}{l}\text { SE } \\
.138\end{array}$} & \multirow{2}{*}{$\begin{array}{c}\mathrm{P} \\
.033\end{array}$} & \multicolumn{2}{|c|}{$\begin{array}{c}\text { Age } \\
\text { Category }\end{array}$} & \multirow{2}{*}{$\begin{array}{c}\begin{array}{c}\text { Mean } \\
\text { Difference } \\
(I-J)\end{array} \\
.633^{*}\end{array}$} & \multirow{2}{*}{$\begin{array}{l}\text { SE } \\
.134\end{array}$} & \multirow{2}{*}{$\begin{array}{c}\mathrm{P} \\
.000\end{array}$} \\
\hline \multirow{15}{*}{$\begin{array}{l}\text { Completing } \\
\text { the rhyme in } \\
\text { a nursery- } \\
\text { rhyme }\end{array}$} & \multirow{5}{*}{1} & 2 & & & & \multirow{5}{*}{4} & 1 & & & \\
\hline & & 3 & $-.343^{*}$ & .144 & .017 & & 2 & $.338^{*}$ & .109 & .002 \\
\hline & & 4 & $-.633^{*}$ & .134 & .000 & & 3 & $.290^{*}$ & .116 & .013 \\
\hline & & 5 & $-.774^{*}$ & .133 & .000 & & 5 & -.142 & .103 & .169 \\
\hline & & 6 & $-.825^{*}$ & .153 & .000 & & 6 & -.192 & .127 & .131 \\
\hline & \multirow{5}{*}{2} & 1 & $.295^{*}$ & 138 & .033 & \multirow{5}{*}{5} & 1 & $.774^{*}$ & .133 & .000 \\
\hline & & 3 & -.048 & ,121 & .694 & & 2 & $.479 *$ & .108 & .000 \\
\hline & & 4 & $-.338^{*}$ & 109 & .002 & & 3 & $.431^{*}$ & .115 & .000 \\
\hline & & 5 & $-.479^{*}$ & ,108 & .000 & & 4 & .142 & .103 & .169 \\
\hline & & 6 & $-.530^{*}$ & 132 & .000 & & 6 & -.051 & .126 & .687 \\
\hline & \multirow{5}{*}{3} & 1 & $.343^{*}$ & .144 & .017 & \multirow{5}{*}{6} & 1 & $.825^{*}$ & .153 & .000 \\
\hline & & 2 & .048 & .121 & .694 & & 2 & $.530^{*}$ & .132 & .000 \\
\hline & & 4 & $-.290^{*}$ & .116 & .013 & & 3 & $.482^{*}$ & .137 & .000 \\
\hline & & 5 & $-.431^{*}$ & .115 & .000 & & 4 & .192 & .127 & .131 \\
\hline & & 6 & $-.482^{*}$ & .137 & .000 & & 5 & .051 & .126 & .687 \\
\hline
\end{tabular}

Note. $\mathrm{p}<.05$

A more detailed look at the comparison of the statistical significance of the differences between age categories showed that there is no statistically significant difference between the four age categories. They include the following: second and third (age: 4.6-5.0 and 5.1-5.5), $(p<.694)$; fourth and fifth (age: 5.6-6.0 and 6.1-6.5), $(p<.169)$; fifth and sixth (age: 6.1-6.5 and 6.6-7.0), $(p<.687)$; fourth and sixth (age: 5.6-6.0 and 6.6-7.0), $(p<.131)$. Therefore, it can be stated that even though the ability of children to complete the rhyme in nursery rhymes improved, this increase is not statistically significant from the age of two to three, from the age of four to five, and from the age of five to six. The given ability thus develops continually for one year, without significant acceleration. The exception was recorded for the children at the age of 4.0 to 4.5 years, for which the results are statistically significant with regard to all age categories, also concerning the category 4.5-5.0. It may thus be stated that from 4.0 to 4.5 years of age, the ability to complete the rhyme to the nursery-rhyme develops the fastest. 


\section{Table 4}

Statistical significance of differences in rhyme awareness

\begin{tabular}{lccccccccc}
\hline Variable & $\begin{array}{c}\text { Age } \\
\text { Category }\end{array}$ & Age & N & M & SD & df & F & p \\
\hline & 1 & $4.0-4.5$ & 83 & 2.24 & 1.686 & & & \\
Rhyme & 2 & $4.6-5.0$ & 160 & 2.82 & 1.722 & & & \\
Awareness & 3 & $5.1-5.5$ & 130 & 3.12 & 1.565 & & & \\
& 4 & $5.6-6.0$ & 192 & 3.38 & 1.551 & 5 & 24.005 & .000 \\
& 5 & $6.1-6.5$ & 204 & 3.97 & 1.362 & & & \\
& 6 & $6.6-7.0$ & 97 & 4.03 & 1.131 & & & \\
\hline
\end{tabular}

Note. $\mathrm{p}<.05$

The results in Table 4 show that with regard to the rhyme awareness tested area, the results in all age categories were found to be statistically significant, on the level of .ooo. It may thus be stated that if the differences found in individual age categories are assessed, they are statistically significant across the entire research sample. For the interpretation of the results and making conclusions, of the research of key importance are the results in Table 1, presenting children's success in rhymes testing. The results in the area rhyme awareness clearly demonstrate that children were improving by age (44.8\%, 56.4\%, 62,4\%. $67,6 \% .79 .2 \%, 80.8 \%$ ). The older the children, the more successful they were at being able to determine better whether two words rhyme. The comparison of statistical significance of the difference for the entire research sample clearly showed that if the children at the age of four to seven years are assessed in a complex way, the increase in their ability is highly evidenced and may be considered to be valid for the whole population. To analyse the differences between the individual age categories in more detail, the LSD test was used; its results are shown in Table 5 below. 


\section{Table 5}

Statistical significance of differences in individual age categories in the area of rhyme awareness

\begin{tabular}{|c|c|c|c|c|c|c|c|c|c|c|}
\hline Variable & \multicolumn{2}{|c|}{$\begin{array}{c}\text { Age } \\
\text { Category }\end{array}$} & \multirow{2}{*}{$\begin{array}{c}\begin{array}{c}\text { Mean } \\
\text { Difference } \\
(I-J)\end{array} \\
-.578^{*}\end{array}$} & & \multirow{2}{*}{$\begin{array}{c}\mathbf{p} \\
.005\end{array}$} & \multicolumn{2}{|c|}{$\begin{array}{c}\text { Age } \\
\text { Category }\end{array}$} & \multirow{2}{*}{$\begin{array}{c}\begin{array}{c}\text { Mean } \\
\text { Difference } \\
(I-J)\end{array} \\
1.139^{*}\end{array}$} & \multirow{2}{*}{$\begin{array}{c}\text { SE } \\
.199\end{array}$} & \multirow{2}{*}{$\begin{array}{c}\mathbf{p} \\
.000\end{array}$} \\
\hline & & 2 & & & & & 1 & & & \\
\hline & & 3 & $-.882^{*}$ & .213 & .000 & & 2 & $.561^{*}$ & .162 & .001 \\
\hline & 1 & 4 & $-1.139 *$ & .199 & .000 & 4 & 3 & .257 & .172 & .136 \\
\hline & & 5 & $-1.725^{*}$ & .198 & .000 & & 5 & $-.585^{*}$ & .153 & .000 \\
\hline & & 6 & $-1.790^{*}$ & .227 & .000 & & 6 & $-.651^{*}$ & .189 & .001 \\
\hline & & 1 & $.578^{*}$ & .205 & .005 & & 1 & $1.725^{*}$ & .198 & .000 \\
\hline & & 3 & -.304 & .179 & .090 & & 2 & $1.147^{*}$ & .160 & .000 \\
\hline \multirow[t]{8}{*}{$\begin{array}{l}\text { Rhyme } \\
\text { Awareness }\end{array}$} & 2 & 4 & $-.561^{*}$ & .162 & .001 & 5 & 3 & $.843^{*}$ & .170 & .000 \\
\hline & & 5 & $-1.147^{*}$ & .160 & .000 & & 4 & $.585^{*}$ & .153 & .000 \\
\hline & & 6 & $-1.212^{*}$ & .195 & .000 & & 6 & -.065 & .187 & .727 \\
\hline & & 1 & $.882^{*}$ & .213 & .000 & & 1 & $1.790^{*}$ & .227 & .000 \\
\hline & & 2 & .304 & .179 & .090 & & 2 & $1.212^{*}$ & .195 & .000 \\
\hline & 3 & 4 & -.257 & .172 & .136 & 6 & 3 & $.908^{*}$ & .204 & .000 \\
\hline & & 5 & $-.843^{*}$ & .170 & .000 & & 4 & $.651^{*}$ & .189 & .001 \\
\hline & & 6 & $-.908^{*}$ & .204 & .000 & & 5 & .065 & .187 & .727 \\
\hline
\end{tabular}

Note. $\mathrm{p}<.05$

A more detailed look at the comparison of the statistical significance showed that there is no statistically significant difference between three age categories. They include the following: second and third (age: 4.6-5.0 and 5.1-5.5), ( $\mathrm{p}<.090)$; third and fourth (age: 5.1-5.5 and 5.6-6.0), $(p<.136)$; fifth and sixth (age: 6.1-6.5 and 6.6-7.0), $(p<.727)$. Therefore, it can be stated that even though the ability of children to become aware of rhyme improved, this increase is not statistically significant from 4.5 to 5.5 years, from five to six years, and from six to seven years of age. The given ability thus develops continually for one year, without significant acceleration. It was shown again that for children at the age of 4.0 to 4.5 years, the results are statistically significant and are different from all other age categories. It may be claimed that the ability to become aware of rhyme develops the fastest in the case of this age group. 
Table 6

Statistical significance of differences in the area of rhyme production

\begin{tabular}{lcccccccc}
\hline Variable & $\begin{array}{c}\text { Age } \\
\text { Category }\end{array}$ & Age & N & M & SD & df & F & P \\
\hline & 1 & $4.0-4.5$ & 83 & 1.66 & 1.684 & & & \\
& 2 & $4.6-5.0$ & 160 & 1.90 & 1.716 & & & \\
Rhyme & 3 & $5.1-5.5$ & 130 & 2.44 & 1.953 & & & \\
Production & 4 & $5.6-6.0$ & 192 & 2.78 & 1.899 & & & \\
& 5 & $6.1-6.5$ & 204 & 3.43 & 1.667 & & & \\
& 6 & $6.6-7.0$ & 97 & 3.65 & 1.595 & & & \\
\hline
\end{tabular}

Note. $\mathrm{p}<.05$

The results in Table 6 show that regarding rhyme production, the results in all age categories were found to be statistically significant, at the level of significance of .ooo. It may thus be stated that if the differences found in individual age categories are assessed, they are statistically significant across the entire research sample. For the interpretation of the results and making conclusions, of key importance are the results in Table 1, presenting children's success in rhymes testing. The results in the area of rhyme production clearly demonstrate that children were improving by age $(33.4 \%, 38.2 \%, 48.6 \%, 55.6 \%$, $68.8 \%, 72.8 \%)$. The older the children, the more successful they were in rhyme production. The comparison of statistical significance of the difference for the entire research sample clearly showed that if the children at the age of four to seven are assessed in a complex way, the increase in their ability is highly evident and may be considered to be valid for the whole population. To analyse the differences between the individual age categories in more detail, the LSD test was used. Its results are shown in Table 7. 


\section{Table 7}

Statistical significance of differences in individual age categories in rhyme production

\begin{tabular}{|c|c|c|c|c|c|c|c|c|c|c|}
\hline Variable & \multicolumn{2}{|c|}{$\begin{array}{c}\text { Age } \\
\text { Category }\end{array}$} & \multirow{2}{*}{$\begin{array}{c}\begin{array}{c}\text { Mean } \\
\text { Difference } \\
(I-J)\end{array} \\
-.237\end{array}$} & \multirow{2}{*}{$\begin{array}{l}\text { SE } \\
.239\end{array}$} & \multirow{2}{*}{$\begin{array}{c}\mathbf{p} \\
321\end{array}$} & \multicolumn{2}{|c|}{$\begin{array}{c}\text { Age } \\
\text { Category }\end{array}$} & \multirow{2}{*}{$\begin{array}{c}\begin{array}{c}\text { Mean } \\
\text { Difference } \\
(I-J)\end{array} \\
1.119^{*}\end{array}$} & \multirow{2}{*}{$\begin{array}{l}\text { SE } \\
.232\end{array}$} & \multirow{2}{*}{$\begin{array}{c}\mathrm{P} \\
.000\end{array}$} \\
\hline & & 2 & & & & & 1 & & & \\
\hline & & 3 & $-.776^{*}$ & .248 & .002 & & 2 & $.881^{*}$ & .189 & .000 \\
\hline & 1 & 4 & $-1.119 *$ & .232 & .000 & 4 & 3 & .343 & .201 & .088 \\
\hline & & 5 & $-1.764^{*}$ & .230 & .000 & & 5 & $-.645^{*}$ & .178 & .000 \\
\hline & & 6 & $-1.987^{*}$ & .264 & .000 & & 6 & $-.868^{*}$ & .220 & .000 \\
\hline & & 1 & .237 & .239 & .321 & & 1 & $1.764^{*}$ & .230 & .000 \\
\hline & & 3 & $-.538^{*}$ & .209 & .010 & & 2 & $1.526^{*}$ & .187 & .000 \\
\hline \multirow[t]{8}{*}{$\begin{array}{l}\text { Rhyme } \\
\text { Production }\end{array}$} & 2 & 4 & $-.881^{*}$ & .189 & .000 & 5 & 3 & $.988^{*}$ & .198 & .000 \\
\hline & & 5 & $-1.526^{*}$ & .187 & .000 & & 4 & $.645^{*}$ & .178 & .000 \\
\hline & & 6 & $-1.749^{*}$ & .228 & .000 & & 6 & -.223 & .218 & .307 \\
\hline & & 1 & $.776^{*}$ & .248 & .002 & & 1 & $1.987^{*}$ & .264 & .000 \\
\hline & & 2 & $.538^{*}$ & .209 & .010 & & 2 & $1.749^{*}$ & .228 & .000 \\
\hline & 3 & 4 & -.343 & .201 & .088 & 6 & 3 & $1.211^{*}$ & .237 & .000 \\
\hline & & 5 & $-.988^{*}$ & .198 & .000 & & 4 & $.868^{*}$ & .220 & .000 \\
\hline & & 6 & $-1.211^{*}$ & .237 & .000 & & 5 & .223 & .218 & .307 \\
\hline
\end{tabular}

Note. $\mathrm{p}<.05$

A more detailed examination of the results showed that there is no statistically significant difference between three age categories: first and second (age: 4.0-4.5 and 4.6-5.0), ( $p<.0321)$; third and fourth (age: 5.1-5.5 and 5.6$6.0)$, ( $p<.088$ ); fifth and sixth (age: 6.1-6.5 and 6.6-7.0), $(p<.307)$. Thus, it can be stated that even though the ability of children to create rhyme improved, this increase is not statistically significant from 4.0 to 5.5 years of age, from 5.0 to 6.0, and from 6.0 to 7.0 years. The given ability thus develops continually for one year, without a significant acceleration.

In the next step of the assessment of results, we attempted to determine whether there is a relation between the tested variables, specifically between the age and the individually tested areas (completing the rhyme of nursery-rhyme, rhyme awareness, rhyme production) as well as between the areas themselves. For these purposes, the Pearson Correlation test was used. The results are presented in Table 8. 


\section{Table 8}

Results of correlations between individual correlations

\begin{tabular}{lccccc}
\hline & & Age & $\begin{array}{c}\text { Completing Rhyme } \\
\text { in Nursery-Rhyme }\end{array}$ & Rhyme Awareness & Rhyme Production \\
\hline Age & $\mathrm{r}$ & 1 & $.242^{* *}$ & $.343^{* *}$ & $.355^{* *}$ \\
& $\mathrm{p}$ & .000 & .000 & .000 \\
\hline $\begin{array}{l}\text { Completing Rhyme } \\
\text { in Nursery-Rhyme }\end{array}$ & $\mathrm{r}$ & 1 & $.422^{* *}$ & $.452^{* *}$ \\
\hline & $\mathrm{p}$ & & .000 & .000 \\
\hline Rhyme Awareness & $\mathrm{r}$ & $\mathrm{p}$ & 1 & $.510^{* *}$ \\
\hline & $\mathrm{r}$ & & & .000 \\
\hline
\end{tabular}

Note. $\mathrm{p}<.05, \mathrm{r}-$ Correlation, ${ }^{* *}$ Correlation is significant at the 0.01 level.

The results show a strong relationship between all the variables. Therefore, the following conclusions may be stated: the correlation relation increases with the child's age with regard to the tested areas. The older the child, the better s/he is able to complete the rhyme of a nursery-rhyme, to become aware of the rhyme, and to produce it. With the increasing age, the ability of children to work with rhymes also becomes better. A very high level of correlation is also shown in the comparison of individually tested areas: to complete the rhyme in nursery-rhymes, to be aware of rhyme, and to produce it. These results show an even stronger relationship than in the comparison of the tested areas with age. One can thus claim that these three variables are in a very strong relation. The ability to complete the rhyme in a nursery-rhyme is a condition for rhyme awareness and the subsequent production of words which rhyme. The strongest correlation was found between rhyme awareness and rhyme production, which means that if the child is not aware of rhyme, s/he is not able to produce it.

\section{Discussion}

This study focused on testing children's ability to complete a rhyming word in a familiar nursery rhyme, to identify a rhyme and, consequently, to create a rhyming word to stimulus words. The final results in individual areas showed that children were most successful in the task of completing rhyme in nursery rhymes, for which $85.65 \%$ of successful responses were observed. The secondhighest level of success (66.79\%) was recorded in the task of becoming aware of rhyme. The least successful was children when producing rhymes (54.18\%). 
When interpreting the results for the task of completing rhymes in nursery rhymes, verbal answers were assessed in detail. The results point to the conclusion that the highest number of non-traditional answers occurred in the nursery rhymes with the lowest percentage of success. At the same time, it can be concluded that the higher the percentage of the most frequent answers, the fewer new (non-traditional) answers occurred. Therefore, it can be concluded that if children did not know the nursery rhyme, they needed to think about new rhyming words. The ability to complete rhyme in nursery rhymes improves with age, and the difference is statistically significant. Simultaneously, the development of this ability is continual and most rapid between the ages of 4.o to 4.5 years. The phonemic awareness development is emphasised in the age group of four to five years old, since some research studies have implied that children younger than four years do not tend to show this ability reliably (Nagy \& Anderson, 1995). From the age of four years, phonemic awareness starts to develop through sensitivity to larger sound units, such as phrases and words, proceeding to smaller sound units, such as syllables and phonemes. All children aged four to seven years should be able to pass the Test of Phonologic and Phonemic Awareness successfully by completing rhymes in nursery rhymes (Máčajová, 2013) in all tested nursery rhymes.

Children's ability to become aware of rhymes (i.e., to determine whether two words are rhyming) improves with age, and the difference is statistically significant. The development of this ability is continual, and it develops most rapidly between $4.0-4.5$ years of age. Children were more successful when identifying two rhyming words in comparison with words which do not rhyme. Significant difficulties were displayed when determining a rhyme in the pair 'komín-kominár' (42\% success). The total success in this area (66.79\%) indicated that children manifested pronounced weaknesses in identifying rhymes of words that were similar in sound but different in meaning.

Regarding rhyme production, meaning the ability to create a rhyming word to a stimulus word, it was concluded that it improves continually with the age of children and the difference is statistically significant. Relatively equivalent results in rhyme production imply that this ability of children is equal in output, without any marked relationship to the character of the tested words. No significant difference was recorded when assessing the variability of answers either, because none of the words stimulated production of a significantly higher percentage of new, non-traditional rhymes.

Children are able to become aware of a rhyme much quicker and much sooner than of individual phonemes, which can be considered to be an adequate starting point for the activities with rhymes in the pre-school age. Rhythm and 
rhymes start to develop as the earliest phonological awareness skills. Rhythm is created by syllables, and if children can 'clap' the syllables of their names or other multisyllabic words, they can 'attune' themselves to the rhythm of the language. Dividing words into syllables is an essential skill in learning to read. The child usually starts to become aware of sound similarities at the end of words and can distinguish them. The understanding of the rhyming requires the knowledge of which part of the word is key in rhyming; thus, the teacher should train the distinction and production of rhymes. If the child can identify and produce rhyme models, such as 'ring', 'sing', 'king', and 'wing', s/he demonstrates early phonemic awareness, because the child leaves out the first phoneme (onset) in the syllable and substitutes it with other ones. Although, in the beginning, the child is not aware of this process, a space is opened for the realisation that words consist of the sequences of simple sounds, which underscores the importance of rhyming activities in kindergarten (Ehri et al., 2001; Nagy \& Anderson, 1995). Therefore, it is recommended that the development of rhyme awareness should begin with nursery rhymes that teach children to become aware of rhyme, followed by training rhyme awareness via determining correspondences between two mutually rhyming, or non-rhyming words, and, finally, asking children to produce rhymes themselves, specifically, by requiring them to create rhymes in response to stimulus words.

What kind of relationship there is between rhyme awareness, phonological awareness, and reading remains an open issue. Some research studies (Dunst et al., 2011; Goswami, 2019; Kuppen \& Bourke, 2017) claim that there is a close relation between rhyme awareness and reading. The findings provide support for 'a relationship between young children's nursery rhyme abilities and their phonological and print-related skills, including emergent reading' (Dunst et al., 2011, p. 1). Macmillan (2002) drew on the findings of some researchers who maintained that rhyme awareness is the cause of reading; she conducted a research in which she tried to detect sensitivity to rhyme, the ability to create rhyme, and, at the same time, the test of reading. The relation of both performances was in the population, especially among beginning readers, very close. However, to create a causal relation from such findings was impossible. While rhyme awareness may be a good starting point for phonological awareness, it does not necessarily have to mean a better awareness of individual sounds. The training and development of rhyme awareness stimulate phonemic awareness, which has a favourable effect on reading performance. Rhyme training, however, does not influence phonematic awareness directly since its development occurs only during the targeted training. Rapid progression may be observed in the tasks aimed at the manipulation with sounds and letters (Macmillan, 2002). 
Jošt (2011) has tested the hypothesis that claimed that the training and development of phoneme awareness stimulate phonemic awareness, and thus, in fact, are decisive in reading performance. The research has shown, however, that the training of rhymes does not have a direct effect on phonemic awareness. Anthony and Lonigan (2004) dealt with children at the age of four to seven years, searching for the relation between rhyme sensitivity and other forms of phonological awareness. In the case of younger children, no difference could be distinguished between rhyme sensitivity and phonemic, segmental, and global phonological awareness. However, in the case of older children, there was a difference between rhyme sensitivity and above-mentioned phonological skills. The result of this was that the sensitivity to rhyme is highly predictive for these phonological skills. Although rhyming is part of phonological awareness (Anthony \& Lonigan, 2004), it seems that it is not necessarily the simplest skill of phonological awareness to master. This means that the rhyming activities include identification and differentiation, in which two or three words rhyme with a chosen word or which one word of the three does not rhyme with the given word (rhyme oddity). Another relatively significant challenge is the activity to produce rhymes. These tasks depend on the fact that words rhyme because they share a common ending sound, and these rhyme tasks represent an assessment of skills in the development of phonological awareness. The evidence from some developmental and intervention samples shows that the competence with the types of tasks for the rhyme completion, rhyme oddity, rhyme production, is formed, on average, at an older age than the ability to manipulate parts of compound words, syllables, and perhaps even some phoneme skills (Philips, Menchetti, \& Lonigan, 2008). Exposing the child to nursery rhymes may help in drawing his/her attention to the sound structure of words, as well as to semantic structure. However, there are several recommendations. For example, with regard to appropriate metalinguistic skills, it could be best to teach rhyming explicitly in the onset-rime context, not as an independent activity. Phonological awareness may be taught through the manipulation of words, syllables, onset-rime, phonemes, and not exclusively or primarily through traditional rhyming activities. Wimmer, Landerl, and Schneider (1994) also determined a relationship between rhyme awareness and reading. The main finding was that it is a developmental change. Rhyme awareness was only slightly predictive for the performance of reading and spelling at the end of the first grade but reached a substantial, predictive meaning with the reading and spelling in the third and fourth grades (results from the structure of the German language), which may be explained through the role it plays during fluent reading and a high level of orthographic skills. The authors assumed that the awareness 
of bigger phonological segments than rhymes affects the fluency of reading and orthographic spelling skills because they influence the ability of the child to create memory representations for written words. Memory representations have a function of distinguishing the units in reading, where they facilitate direct access to pronunciation and meaning and ensure orthographically correct spelling (Perfetti, 2007). The acquisition of the predictive meaning of rhyme awareness is explained by its usefulness for the creation of mental representations of written words. Some scholars emphasised the importance of sensitivity to rhyme in the initial reading, while others underscored the sensitivity to phonemes. Anthony and Lonigan (2004) determined that the measurement of rhyme sensitivity (except for rhyme production) and sensitivity to phonemes were indicators of the same ability, which led them to the conclusion that 'the effects of sensitivity to rhyme and phonemes are probably not unique in the situations in which words may be read analogically or through letter-sound correspondence' (p. 49). The conceptualisation of phonological awareness provides a certain advantage of rhyme sensitivity in the case of reading through analogy and sensitivity to phonemes in the case of reading through letter-sound correspondence. Both these phonological skills influence reading (Anthony \& Francis, 2005; Catts et al., 2001; Ehri et al., 2001, etc.). The above research identified rhyme awareness as a precursor to the development of literacy. Kuppen and Bourke (2017) determined that knowing nursery rhymes at the age of three was predictive to the reading of words at the age of six. Metanalyses also indicate a slightly predictive role of rhyme awareness in subsequent literacy development. Learning the spoken rhythmical nursery rhymes may thus support phonological awareness.

\section{Conclusion}

The importance of rhyme awareness is undeniable concerning phonological awareness. The studies and research that both support and challenge the importance of rhyme awareness in connection with initial literacy are relatively numerous. Our testing of the pre-school age children with regard to phonological and phonemic awareness was expected to point to empirical findings that help predict possible problems in the initial literacy and the importance of these activities in pre-primary education. We can state that the tested items on rhyming are possible to generalise on a population of pre-schoolers; these items were approved statistically and became a part of a large diagnostic instrument evaluating the level of phonological awareness. It was determined that children in the investigated age groups were able to complete rhymes in well-known 
nursery rhymes, able to become aware of rhyme and could produce rhymes. According to these tested items and possible poor results (under the norm), we can detect children who are at risk in initial instruction of reading and writing; they need special attention before entering the first year of primary school, and activities are oriented on teacher's intervention in kindergarten. As mentioned above, the diagnostic instrument is focused not only on rhyme testing but also on following subtests. Other tested abilities in close connection to phonological and phonemic awareness were analysis and synthesis at the level of words, syllables, and sounds (phonemes); omission of phonemes and syllables; isolation of phonemes and syllables; word differentiation and localisation of changes in the sentences. We can conclude that phonological and phonemic awareness predict a child's level of abilities to read and write. Therefore, it is necessary to continue identifying various language abilities related to phonological awareness and research their part (proportion) in successful reading. This diagnostic test should be a valid and reliable instrument for a teacher to assess the level of phonological and phonemic awareness of pre-schoolers, and to detect children at risk in initial reading and writing. Teachers' competences in developing children's early literacy are developed during undergraduate studies in pre-school and primary education study programmes. Courses are focused on the theory of language development and early literacy as well as training in methods and strategies for developing a child's pre-reading and pre-writing skills.

\section{Acknowledgement}

The study was written as an outcome of the research project VEGA no.1/0637/16 The Development of the Diagnostic Instrument for the Assessment of the Level of Phonemic Awareness of Pre-School Age Children. 


\section{References}

Adams, M. J. (1990). Beginning to read: Learning and thinking about print. MIT Press.

Adams, M., Foorman, B., Lundberg, I., \& Beeler, T. (1998). Phonemic awareness in young children. $13^{\text {th }}$ edition. Brookers Publishing Co.

Andersson, S., Sandberg, G., \& Garpelin, A. (2019). To teach writing: Teachers' perspectives on how to promote children's writing development in the Swedish pre-school class. Nordic Journal of Literacy Research, 5(2), 23-38.

Anthony, J. L., \& Lonigan, Ch. J. (2004) The nature of phonological awareness: Converging evidence from four studies of pre-school and early grade school children. Journal of Educational Psychology, 96(1), 43-55. https://doi.org/10.1037/0022-0663.96.1.43

Anthony, J. L., \& Francis, D. J. (2005). Development of phonological awareness. Current Directions in Psychological Science, 14(5), 255-259.

Catts, H. W., Fey, M. E., Zhang, X., \& Tomblin, J. B. (2001). Estimating the Risk of Future Reading Difficulties in Kindergarten Children: A Research-Based Model and Its Clinical Implementation. Language, Speech, And Hearing Services in School, 32(1), 38-50. https://doi.org/10.1044/o1611461(2001/004)

Cséfalvay, Z., Lechta, V. (2013). Diagnostika narušené komunikační schopnosti u dospělých [Diagnosis of impaired communication skills in adults]. Portál.

Culatta, B., Hall, K., Kovarsky, D., \& Theadore, G. (2007). Contextualised approach to language and literacy (Project CALL). Communication Disorders Quarterly, 28(4), 216-235. https://doi. org/10.1177/1525740107311813

Dunst, C. J., Meter, D., \& Hamby, D. W. (2011). Relationship between young children's nursery rhyme experiences and knowledge and phonological and print-related abilities. CELLreview, 4(1), 1-12. Ehri, L. C., Nunes, S. R., Willows, D. M., Schuster, B. V., Yaghoub-Zadeh, Z., \& Shanahan, T. (2001). Phonemic awareness instruction helps children learn to read: Evidence from the National Reading Panel's meta-analysis. Reading Research Quarterly, 36(3), 250-287.

Featherstone, S. (2017). Making sense of neuroscience in the early years. Bloomsbury.

Grofč́́ková, S., \& Máčajová, M. (2017). Abilities of phonological awareness in the context of cognitive development in pre-school age. Journal of Language and Cultural Education, 5(3), 46-56. https://doi. org/10.1515/jolace-2017-0027

Goswami, U. (2015). Children's cognitive development and learning. Cambridge Primary Review Trust, Pearson Education.

Goswami, U. (2019). A neural oscillations perspective on phonological development and phonological processing in developmental dyslexia. Language and Linguistics Compass, 13(5), 1-21. https://doi.org/https://doi1o.1111/lnc3.12328

Hogan, T. P., Catts, H. W., \& Little, T. D. (2005). The Relationship Between Phonological Awareness and Reading: Implications for the Assessment of Phonological Awareness. Language, Speech, and Hearing Services in Schools, 36(4), 285-293. https://doi.org/10.1044/0161-1461(2005/029) 
Jošt, J. (2011). Čtení a dyslexie [Reading and dyslexia]. Grada Publishing.

Kuppen, S. E. A., \& Bourke, E. (2017). Rhythmic rhymes for boosting phonological awareness in socially disadvantaged children. Mind, Brain, And Education, 11(4), 181-189. https://onlinelibrary. wiley.com/doi/pdf/10.1111/mbe.12148

Máčajová, M. (2013). Habilitačná práca [Habilitation thesis]. PF UKF.

Máčajová, M., Grofčíková, S., \& Zajacová, Z. (2017). Fonologické uvedomovanie ako prekurzor vývinu gramotnosti [Phonological awareness as a precursor of literacy development]. UKF.

Mann, V. A., \& Foy, J. G. (2007). Speech development patterns and phonological awareness in preschool children. Annals of Dyslexia, 57(1), 51-74. http://www.jstor.org/stable/23764526 Macmillan, B. M. (2002). Rhyme and reading: A critical review of the research methodology. Journal of Research in Reading, 25(1), 4-42. https://doi.org/10.1111/1467-9817.00156

McBride-Chang, C. (1995). What is phonological awareness? Journal of Educational Psychology, 87(2), 179-192.

Moats, L. C. (2000). Speech to print: Language essentials for teachers. Brookers Publishing Co. Nagy, W. E., \& Anderson, R. C. (1995). Metalinguistic awareness and literacy acquisition in different languages. University of Illinois, College of Education. https://www.ideals.illinois.edu/bitstream/ handle/2142/17594/ctrstreadtechrepvo1995ioo618_opt.pdf Ozernov-Palchik, O., Wolf, M., \& Patel, A. D. (2018). Relationships between early literacy and nonlinguistic rhythmic processes in kindergarteners. Journal of Experimental Child Psychology, 167(2018), 354-368. https://doi.org/10.1016/j.jecp.2017.11.009

Perfetti, Ch. (2007). Reading ability: Lexical quality to comprehension. Scientific studies of Reading, 11(4), 357-383. https://doi.org/10.1080/10888430701530730

Philips, B. M., Menchetti, J. C., \& Lonigan, Ch. J. (2008). Successful phonological awareness instruction with pre-school children: Lessons from the classroom. Topics Early Childhood Special Education, 28(1), 3-17. https://doi.org/10.1177/0271121407313813

Reading, S., \& Van Deuren, D. (2007). Phonemic awareness: When and how much to teach? Reading Research and Instruction, 46(3), 267-285. https://doi.org/10.1080/19388070709558471

Tomšik, R. (2017). Kvantitatívny výskum v pedagogických vedách: úvod do metodológie a štatistického spracovania [Quantitative research in educational sciences: introduction to methodology and statistical processing]. UKF.

Torgesen, J. K. (2002). The prevention of reading difficulties. Journal of School Psychology, 4o(1), 7-26. https://doi.org/10.1016/Soo22-4405(01)00092-9

Wimmer, H., Landerl, K., \& Schneider, W. (1994). The role of rhyme awareness in learning to read a regular orthography. British Journal of Developmental Psychology, 12(4), 469-484. https://doi. org/10.1111/j.2044-835X.1994.tboo648.x Žilka, T. (2011). Vademecum poetiky [Handbook of poetics]. UKF. 


\section{Biographical note}

SoŇA Grofčínová, $\mathrm{PhD}$, is an assistant professor in the field of pedagogy at the Faculty of Education at Constantine the Philosopher University in Nitra, Slovakia. Her main areas of interest are preschool and primary education, theory of education, theory of instruction and didactics, language development and literacy. She is involved in European international projects focused on early childhood education.

Monika Máčajová, PhD, is an associated professor in the field of pedagogy at the Faculty of Education at Constantine the Philosopher University in Nitra, Slovakia. Her main areas of research are preschool and primary education, theory of instruction, didactics of reading and writing, literacy development, creativity development. 